\title{
Social networking experiences on Facebook: A survey of gender differences amongst students
}

\begin{abstract}
Authors:
Melanie Wiese ${ }^{1}$

Juanne Lauer ${ }^{1}$

George Pantazis

Jade Samuels ${ }^{1}$
\end{abstract}

\section{Affiliations:}

${ }^{1}$ Department of Marketing

Management, University of

Pretoria, South Africa

\section{Correspondence to:}

Melanie Wiese

Email:

melanie.wiese@up.ac.za

Postal address:

PO Box 20, Hatfield 0028,

South Africa

Dates:

Received: 06 Aug. 2013

Accepted: 12 May 2014

Published: 12 Nov. 2014

How to cite this article: Wiese, M., Lauer, J., Pantazis, G. \& Samuels, J., 2014, 'Social networking experiences on Facebook: A survey of gender differences amongst students', Acta Commercii 14(1), Art. \#218, 7 pages. http://dx.doi.org/10.4102/ ac.v14i1.218

\section{Copyright:}

(C) 2014. The Authors. Licensee: AOSIS OpenJournals. This work is licensed under the Creative Commons Attribution License.
Orientation: Students' membership and participation in social networking sites, such as Facebook, has increased in recent years.

Research purpose: The study examined students' access to social network sites and compared male and female students' usage of Facebook with regards to time commitment, privacy concerns, and the creation and/or maintenance of relationships.

Motivation: The study adds to the existing academic literature on this topic by providing a South African perspective.

Research design, approach and method: Two-hundred self-administered questionnaires were distributed using convenience sampling. The statistical analysis that was used included Mann-Whitney $U$-test, $t$-test and ANOVA analysis.

Main findings: Students connect to social networking sites everyday primarily via their mobile phones. Female students reported spending more time on Facebook whilst at the same time expressing more concern for their privacy. Moreover, students were found to use Facebook to maintain existing offline friendships more so than creating new relationships.

Managerial implications: Social networking sites such as Facebook play an important role in students' everyday interpersonal communication. Practically, Facebook provides lecturers, parents and businesses the opportunity to communicate with students in a fast and cost-effective way. Therefore, insight into the variables studied could help marketers and Social Network Site operators to manage privacy concerns in order to effectively target, advertise and communicate with students.

Contribution: Although past research has concentrated on the study of Facebook in terms of privacy and members' uses little research has been conducted on gender differences in this regard, more so within a South African context. Furthermore demographic variables such as gender influence motives and behaviour, as such making the analysis demographics essential.

\section{Introduction}

The Internet provides a platform through which university students can make use of computermediated communication (CMC) applications such as email, instant messaging and social network sites (Vrocharidou \& Efthymiou 2012). According to Vrocharidou and Efthymiou (2012), university students are avid CMC users with social network sites (SNSs) representing the fastestgrowing and most popular Internet-based technology amongst young people (Roblyer et al. 2010). They provide an easy and accessible virtual environment through which one can interact and communicate with others within and beyond their societal and geographical proximities (Kim, Sohn \& Choi 2011; Pempek, Yermolayeva \& Calvert 2009).

Students make use of many SNSs, however, Facebook appears to be the network of choice amongst this group and as such has 'revolutionized [their] social behaviours and networking practices' (Kalpidou, Costin \& Morris 2011:183). Hew (2011) suggests that Facebook is primarily used to maintain existing offline relationships but at the cost of potential privacy risks through the disclosure of personal information. Although past research has concentrated on the study of Facebook in terms of privacy (Acquisti \& Gross 2006; Debatin et al. 2009; Hoy \& Milne 2010; Lewis, Kaufman \& Christakis 2008) and members' uses (Ellison, Steinfield \& Lampe 2007; Hew 2011; Pempek et al. 2009; Valenzuela, Park \& Kee 2009), little research has been conducted on gender differences in this regard, especially within a South African context.

The purpose of this study was to analyse gender differences toward the usage of SNSs amongst South African university students. Boyd and Ellison (2008) report that there is limited research conducted outside of the United States of America on who is using social network sites and for 
what purpose. With regard to gender differences, research on media patterns suggests that demographic variables influence motives and behaviour and it can thus be inferred that demographic variables may affect Facebook users' behaviour, making the analysis of demographics essential (Giannakos et al. 2012). This then serves as an impetus to conduct such a study within a South African context. The specific research objectives that guided the study were as follows:

- To determine which social network sites are used most often by students.

- To determine how often students access social network sites.

- To determine if students access social network sites by means of a computer or mobile phone.

- To determine if there are gender differences amongst students with regard to:

- time spent on Facebook

- concern for privacy on Facebook

- using Facebook to form new online relationships or maintain existing offline relationships.

\section{Social networking}

The Internet can be considered to be a multi-faceted mass medium of communication (Morris \& Ogan 1996). Its advent has been deemed by many as revolutionary (Stafford, Stafford \& Schkade 2004) because of its radical and profound impact on the manner in which people communicate, especially since the popularity of SNSs. Over the years the usage rates of the Internet have grown exponentially. In 2000, the record of active Internet users was 360985492 and the latest statistics, as at the end of 2012, have the number of active users recorded at 2405518376 (Internet World Stats 2014). The significant growth rate of Internet usage is thus compelling researchers to investigate and examine the motivations behind it (Stafford et al. 2004). According to Rafaeli (1986), the theory of uses and gratifications is deemed an appropriate theoretical framework on which to understand the motivations behind the usage of a mass medium, such as the Internet.

Stafford et al. (2004:259) define this theoretical model as 'a communications' research paradigm that determines motivations by focusing on what people do with mass media'. The approach of uses and gratifications can simply be portrayed as the 'how and why' behind media use motivations.

With the rise in Internet accessibility comes the territory of new Internet technologies that are able to support numerous relationships and communities, such as social networking websites (Golder, Wilkinson \& Huberman 2007). On the basis of the uses and gratifications theory, it is hypothesised that consumers use forms of mass media, such as online social networks, for different goals and purposes, depending on their needs (Roberts 2010). The assumptions upon which the theory is based include the fact that (1) the audience is active,
(2) the media choice lies with the audience member, (3) all media compete with other sources of need/goal fulfilment, (4) mass media goals can be found in the message of the source, and (5) cultural value judgements should be not be taken into consideration as the audience explores their own opinions (Roberts 2010).

Pempek et al. (2009) define online social networks as 'member-based Internet communities' that allow members to share profile information and communicate with others. By the same token, Boyd and Ellison (2008:211) describe SNSs as 'web-based services that allow individuals to (1) construct a public or semi-public profile within a bounded system, (2) articulate a list of other users with whom they share a connection, and (3) view and traverse their list of connections and those made by others within the system'. In principal, SNSs allow members to reflect, extend and share their personalities with their online communities. SNSs can be oriented toward various contexts, such as one's professional career (e.g. LinkedIn), common interests (e.g. music on MySpace), or university students - the original purpose of Facebook (Ellison et al. 2007). Miller, Parsons and Lifer (2010) reported that the use of social networking sites by students is significant. The vast majority of students (85\%) indicated that they visited these sites at least once a day.

The theoretical framework of the uses and gratifications theory is thus a solid foundation upon which this study can build on, in terms of 'how and why' online social networks (such as Facebook) are used by individuals to satisfy their communication needs.

\section{Facebook as a social networking site}

Facebook was founded in 2004 to allow for online social interaction between students at Harvard University (Nosko, Wood \& Molema 2010). In 2006, Facebook became available to the general public (Stern \& Taylor 2007) and in March 2013 Facebook claimed 1.11 billion monthly active users (Facebook 2013).

Facebook allows its members 'to stay connected with friends and family, to discover what's going on in the world, and to share and express what matters to them' (Facebook 2013). This is, in principal, done by building an online 'profile' containing one's personal information and uploaded digital pictures (Pempek et al. 2009). In addition, Facebook involves accumulating 'friends' with whom one wishes to stay in contact, communicating with these 'friends' via comments posted on their 'walls' (personal message boards) or private messages (similar to email), joining groups based on common interests and becoming a 'fan' of one's favourite organisation or celebrity (Ellison et al. 2007; Hew 2011; Pempek et al. 2009).

The current study examined the use of Facebook by South African undergraduate university students. Previous research by Ellison et al. (2007) found that $94 \%$ of the American undergraduate students surveyed used Facebook. More recently, Kim et al. (2011) report that Facebook is the 
most popular SNS, used most frequently (83.4\%) amongst American undergraduate respondents. According to Socialbakers (2012), a social media and digital analytics company, there are 4.6 million South African Facebook users of which $30 \%$ are between the ages of 18 and 24, the typical age group of South African undergraduate university students. Whilst it seems fair to conclude that Facebook has a large percentage of undergraduate university members, there are gender differences in the adoption of communication technology (Hargittai 2008; Junco, Merson $\&$ Salter 2010). The inherency of gender differences within the adoption of communication technology thus serves as the impetus for studying gender differences by means of Facebook. According to Socialbakers (2012), the gender split of South African Facebook users is an even 50\%.

\section{The gender differences}

The literature review that follows summarises previous research in respect of time spent on Facebook, privacy concerns and the establishment and/or maintenance of relationships.

\section{Time spent on Facebook}

Pempek et al. (2009) state that Facebook is incorporated into the daily lives of students. In March 2013, Facebook reported an average of 655 million daily active users. Previous researchers have found that students spend between 10 and 60 minutes on Facebook daily (Ellison et al. 2007; Muise, Christofides \& Desmarais 2009; Pempek et al. 2009; Ross et al. 2009; Valenzuela et al. 2009). More recently-published studies, however, report averages as high as 81.4 minutes (Ellison, Steinfield \& Lampe 2011) and 101.09 minutes per day (Junco et al. 2010). Giannakos et al. (2012) found that respondents with an average age of 25 years spend approximately 8.24 hours a week on Facebook. Golder et al. (2007) found that students spend less time on Facebook over the weekends as this is when they are away from their computers. However, with advances in mobile technology, this is likely to change. In March 2013, Facebook reported 751 million monthly active mobile users.

With regard to gender differences, Muise et al. (2009) found that female students in Canada spend significantly more time on Facebook than their male counterparts. Furthermore, although the researchers did not ask respondents to indicate actual time spent on Facebook, Hoy and Milne (2010) report that female respondents checked their Facebook profiles more frequently; $78.6 \%$ of females checked their profiles several times per day compared with $67.7 \%$ of males. It is therefore hypothesised that:

$\mathbf{H}_{1}$ : Female university students spend more time on Facebook on a daily basis than male university students.

\section{Privacy concerns on Facebook}

Internet users are becoming increasingly aware and concerned about the power Internet technologies have in monitoring user behaviour and gathering personal information without one's knowledge (Dinev \& Hart 2004). A study in Hong Kong found that students are highly concerned about how organisations gather and disseminate customers' personal information through the Internet (Yao \& Zhang 2008). The researchers further found that more experienced Internet users and more frequent users were more concerned about online privacy.

Privacy, in its more conventional sense, refers to the 'right to prevent the disclosure of personal information to others' (Paine et al. 2007:526). Facebook, by default, allows members of the same network to view each other's profiles (Boyd \& Ellison 2008). This means that personal information is potentially available to friends as well as complete strangers. Previous research has found that students are significantly more likely to divulge information about themselves on Facebook (Muise et al. 2009), thereby opening themselves up to potential privacy risks (Hew 2011). Christofides, Musie and Desmarais (2009) report, however, that students are, in general, concerned about their privacy and thus likely to make use of privacy settings.

Several studies have identified gender differences with regard to online privacy concerns, however, not all are within the realms of Facebook. In an analysis of five Web situations, Sheehan (1999) states that women's personal privacy concerns were higher than those reported by men. Fogel and Nehmad (2009) found a greater degree of privacy concerns with regard to SNSs amongst female undergraduate students. Regarding to young adult Facebook users, Hoy and Milne (2010:33) state that women were 'significantly more concerned than men about the privacy of the information about (them) that's posted on Facebook'. However, the researchers also state that both genders' privacy concerns were low. Overall, females report being more concerned with privacy than men and thus it is hypothesised that:

$\mathbf{H}_{2}$ : Female university students have a greater concern for privacy on Facebook compared with that of male university students.

\section{The creation and/or maintenance of relationships on Facebook}

Social network sites, such as Facebook, can be seen as a communication platform that supports both existing social ties as well as the formation of new social connections (Ellison et al. 2007, 2011). Giannakos et al. (2012) found that 'social connection' is the main reason for using Facebook. One question that arises, however, is whether these sites are used primarily to form new online relationships or to maintain existing offline relationships (Ellison et al. 2011). Previous research provides evidence in support of the latter (Bosch 2009; Ellison et al. 2007, 2011; Pempek et al. 2009; Raacke \& Bonds-Raacke 2008). Hew (2011) identified nine motives for using Facebook, the main use being social interaction to maintain existing offline relationships, such as with current friends, classmates, or someone that lives nearby. Pempek et al. (2009) found that $68.48 \%$ of students 
would only accept a friend request on Facebook from someone they knew offline as opposed to $23.91 \%$ who would accept a friend request from anyone that asked. Moreover, the researchers state that $77.17 \%$ of students report that 'none of their Facebook friendships originated online'. Giannakos et al. (2012) found that Facebook was used to connect with people who are geographically dispersed or to reconnect with old friends. Miller et al. (2010) report that $92 \%$ of students in their study used Facebook to stay in contact with old friends, whilst only $42 \%$ used it to meet new people.

Haferkamp et al. (2012) postulate that, based on genderrelated differences in Internet communication and behaviour in general, it can be assumed that men and women have different motives regarding their SNS usage as well. Weiser (2000), in a study on gender differences in Internet use, reports that women primarily use the Internet for interpersonal communication with geographicallyseparated friends and family. Men, on the other hand, were found to use the Internet primarily for entertainment and leisure purposes. Similarly, Muscanell and Guadagno (2012) and Barker (2009) provide evidence that female students use SNSs to maintain relationships whereas male students use these sites to form new relationships. Thus, it is hypothesised that:

$\mathbf{H}_{3}$ : Female university students use Facebook mainly to maintain existing offline relationships whilst male university students use Facebook mainly to create new online relationships.

\section{Research method and design \\ Sample}

The sample comprised 200 undergraduate university students, 102 female (51\%) and 98 male (49\%), who were members of Facebook. The decision to use university students and limit it to those with Facebook accounts was deemed appropriate because of the popularity of Facebook amongst this group, as mentioned previously. Respondents were approached based on convenience via campus-intercept on the University of Pretoria's main campus and asked to complete a self-administered questionnaire after informed consent was obtained. Students were not incentivised to complete the questionnaire.

\section{Measures}

The questionnaire contained multiple choice as well as singleand multiple-response questions in order to determine which SNSs students access, how often they access them, by which means (i.e., via computer or mobile phone) and their preferred access method.

Time spent on Facebook was measured by means of the following open-ended question: 'How many minutes on average did you spend on Facebook yesterday?'

Concern for one's privacy on Facebook was measured by means of a four-item scale adapted from Dinev and Hart's (2004) Internet privacy scale. Modifications were required to reflect the specificity of Facebook. The items were rated on a seven-point Likert scale anchored from (1) 'strongly disagree' to (7) 'strongly agree'. Sample items include 'I am concerned that the information I submit on Facebook could be misused' and 'I am concerned about posting information on Facebook because of what other might do with it'. The Cronbach's alpha coefficient for this adapted scale was 0.82 , which indicates acceptable internal consistency reliability.

To investigate whether Facebook members used the site more to maintain relationships with offline contacts or to form new online contacts, the 'Off to Online' and 'On to Offline' scales of Ellison et al. (2007) were adapted, respectively. The items were rated on a seven-point Likert scale anchored from 'strongly disagree' to 'strongly agree' and included items such as 'I use Facebook to learn more about other people in my classes', 'I use Facebook to learn more about other people living near me' and 'I use Facebook to meet new people'. The Cronbach's alpha coefficients for the adapted 'On to Offline' scale and 'Off to Online' scale were 0.78 and 0.64 , respectively. According to Hair et al. (1998), reliability coefficients above 0.60 are satisfactory for exploratory research and those above 0.70 are acceptable.

\section{Results}

\section{Students' access to social network sites}

Table 1 below provides some basic descriptive data to characterise undergraduate students' access to social network sites. The results indicated that, in addition to Facebook, students also access YouTube (64\%), Twitter (38.5\%) and, to a lesser degree, various other SNSs (31\%) such as Mxit and WhatsApp. The latter two can be described as a combination of instant messenger and social network. The majority of students' access SNSs one to three times a day (41\%) or are connected most of the day (39\%). Students use both their mobile phone $(89.5 \%)$ and computer $(79.5 \%)$ to access social networks, however, the preferential method is their mobile phones (51\%).

TABLE 1: Students' access to social network sites.

\begin{tabular}{lll}
\hline Social network variables & $\boldsymbol{n}$ & $\mathbf{\%}$ \\
\hline Social networks used & 200 & 100 \\
Facebook & 77 & 38.5 \\
Twitter & 128 & 64 \\
YouTube & 62 & 31 \\
Other & & \\
How often social networks are used & 78 & 39 \\
Connected most of the day & 82 & 41 \\
Connected 1-3 times during the day & 32 & 16 \\
Connected 1-3 times during the week & 8 & 2 \\
Connected 1-3 times during the month & 200 & 100 \\
Total & & \\
How social networks are accessed & 159 & 79.5 \\
Computer & 179 & 89.5 \\
Mobile & 102 & 51 \\
Method of access preferred when accessing social networks & \\
Computer & 98 & 49 \\
Mobile & 200 & 100 \\
Total &
\end{tabular}




\section{Results for hypotheses}

All the hypotheses were tested at a 5\% level of significance (i.e., $\alpha=0.05$ ) using the independent samples $t$-test $\left(\mathrm{H}_{1}\right.$ and $\left.\mathrm{H}_{2}\right)$ and general linear model (repeated analysis of variance [ANOVA] $)\left(\mathrm{H}_{3}\right)$. Where the assumptions were not met, the appropriate non-parametric alternatives were used.

\section{Time spent on Facebook}

The first hypothesis $\left(\mathrm{H}_{1}\right)$ focused on the difference between male and female university students with regard to time (calculated in minutes) spent on Facebook daily. The assumption of normality, assessed through the KolmogorovSmirnov test for normality as well as through a visual inspection of histograms and normal probability plots, indicated departures from normality in both subsamples. As such, the non-parametric Mann-Whitney $U$-test was used to test $\mathrm{H}_{1}$.

The results indicated that female university students spent more time on Facebook on a daily basis $(\mathrm{M}=33.47, \mathrm{SD}=16.32)$ than their male counterparts $(\mathrm{M}=19.0, \mathrm{SD}=33.20)$. This is consistent with previous research. Muise et al. (2009) report that female students spend on average 40.57 minutes on Facebook compared with the 29.83 minutes of their male counterparts. The results of the Mann-Whitney $U$-test indicated that there was a significant difference $(p=0.0035)$ between male and female university students with regard to time spent on Facebook daily. Thus, $\mathrm{H}_{1}$ was accepted.

\section{Privacy concerns on Facebook}

Hypothesis 2 focused on the difference between male and female university students' concern for privacy on Facebook. The descriptive statistics indicated a difference in the mean scores of men $(M=3.98, S D=1.29)$ and women $(M=4.38$, $\mathrm{SD}=1.32$ ). Thus, female university students reported slightly higher concerns for privacy on Facebook as opposed to male university students. This is in line with previous research by Sheehan (1999) and Fogel and Nehmad (2009) who report that women's personal privacy concerns were higher than men in Web and general SNS situations. The KolmogorovSmirnov test for normality indicated mild departures from normality in both the male and female university student subgroups. However, the independent samples $t$-test is robust for mild departures from normality with large samples; hence it was used to test $\mathrm{H}_{2}$ (Pallant 2005). The results of the $t$-test, assuming equal variances $(t[198]=$ -2.10, $p=0.037$ ), indicated that there was a significant twotailed difference in the mean scores of the male and female subgroups on the concern for privacy scale. However, for privacy concerns, a one-tailed (directional) hypothesis was stated. The one-tailed $p$-value of 0.0186 is smaller than the significance level of $0.05 . \mathrm{H}_{2}$ is thus accepted.

\section{The creation and/or maintenance of relationships on Facebook}

Hypothesis 3 focused on the difference between male and female university students in their use of Facebook to
TABLE 2: Descriptive results.

\begin{tabular}{lllll}
\hline Variables & Gender & $\mathbf{M}$ & $\boldsymbol{n}$ & SD \\
\hline Maintaining existing relationships & Male & 4.066 & 98 & 1.38 \\
& Female & 4.338 & 102 & 1.44 \\
Creating new friendships & Male & 2.459 & 98 & 1.40 \\
& Female & 2.701 & 102 & 1.22 \\
\hline
\end{tabular}

M, mean; SD, standard deviation.

maintain existing offline relationships or create new online relationships.

A general linear model, repeated measures ANOVA (gender as the independent variable and relationships as the dependent variables) with a Greenhouse-Geisser correction determined that the use of Facebook differed significantly between maintaining existing relationships and creating new friendships $(F=233.45, p=0.000)$. However, no significant difference was identified between men and women $(F=0.02$, $p=0.887$ ) and their use of Facebook in this regard. It is clear from Table 2 that both male and female university students use Facebook to maintain existing offline relationships rather than create new online relationships. Thus, there is no support for $\mathrm{H}_{3}$.

\section{Ethical considerations}

Ethical clearance was obtained for this study from the Registrar as well as the Research Ethics Committee of the University of Pretoria.

\section{Trustworthiness}

No potential risks were involved for participants. Participation was voluntarily as students were approached on campus and no incentives were provided to partake in the study.

Informed consent was obtained from all participants who signed an informed consent form that indicated the purpose and use of the research as well as ensuring confidentiality and providing them with the opportunity to stop participating at any time.

The dataset of the raw material is stored, according to the University of Pretoria's ethical guidelines, for 10 years.

\section{Discussion}

The results indicated that university students connect to SNSs every day primarily with their mobile phones. This suggests that there is a possible opportunity to communicate with this group every minute of every day. Whilst other SNSs such as YouTube are somewhat popular amongst students, Facebook is, for the time being, their SNS of choice. However, gender differences in the use of Facebook do exist.

Consistent with previous research (Hoy \& Milne 2010; Muise et al. 2009), South African female university students reported spending more time on Facebook whilst at the same time expressing more concern for their privacy on Facebook. 
In line with their original purpose, SNSs encourage members to spend time posting and sharing personal information about themselves to facilitate online social interactions (Muise et al. 2009). Kolek and Saunders (2008) found that female undergraduate students disclosed more personal information about themselves on their Facebook profiles. This raises privacy concerns (Acquisti \& Gross 2006). Although Christofides, Musie and Desmarais (2009) reported that students are, in general, concerned about their privacy, for this study's sample, the concern for privacy on Facebook for both genders is limited (Women, $\mathrm{M}=4.38$; $\mathrm{Men}, \mathrm{M}=3.98$ on a seven-point Likert scale). This may be because students have control over the personal information posted, believe they have some control over its accessibility (Acquisti \& Gross 2006), engage in active profile management, or simply are not concerned about being judged about the information on their profiles (Ellison et al. 2011). The lack of concern is also driven in some way by the benefits gained from using or participating on SNSs (Hoy \& Milne 2010).

Much like traditional communication tools, Facebook is used to keep in touch with others. The results of the present study indicated that South African university students use Facebook more to maintain existing offline relationships rather than to create new online relationships. This is in line with Courtois, All and Vanwynsberghe (2012) who state that 'SNSs are valuable sources of information for offline relations' as the content made available on SNSs enables one to learn more about acquaintances and close friends. From a practicality standpoint, Facebook provides lecturers, parents and businesses the opportunity to communicate with students in a fast and cost-effective way (Schlenkrich \& Sewry 2012). University students may also reap the benefits of staying in touch with alumni who may provide possible future career opportunities.

\section{Conclusion}

In conclusion, Facebook is a popular destination for students to engage in their everyday online social activities and thereby strengthen their existing social networks. Albeit that SNSs present privacy concerns, undergraduate Facebook members are not deterred by this. This study contributed to existing academic literature regarding gender differences in Facebook usage. However, a few limitations are worth noting. Gender differences were only assessed via one SNS, namely, Facebook. In addition, the sample consisted solely of students at the University of Pretoria in South Africa selected via a non-probability sampling method. The results of this study can therefore not be generalised to a larger population or other SNSs. Future research could explore privacy risks in more detail as well as investigate possible gender difference in the motives for using other SNS. The use of SNSs, such as Facebook, to support education initiatives should also be investigated.

\section{Acknowledgements}

This work is based on the research supported in part by the
National Research Foundation (NRF) of South Africa for the grant, Unique Grant No. 84258. Any opinion, finding and conclusion or recommendation expressed in this material is that of the author(s) and the NRF does not accept any liability in this regard.

\section{Competing interests}

The authors declare that they have no financial or personal relationship(s) which may have inappropriately influenced them in writing this article.

\section{Authors' contributions}

M.W. and J.L. (both University of Pretoria) were the supervisors and project leaders and made conceptual and editorial contributions. G.P. and J.S. (both University of Pretoria) gathered and captured the data. The statistical analysis and writing of the manuscript were a combined effort.

\section{References}

Acquisti, A. \& Gross, R., 2006, 'Imagined communities: Awareness, information sharing, and privacy on the Facebook', Privacy Enhancing Technologies 4258, 36-58. http://dx.doi.org/10.1007/11957454_3

Barker, V., 2009, 'Older adolescents' motivations for social network site use: the influence of gender, group identity, and collective self-esteem', CyberPsychology \& Behavior 12(2), 209-213. http://dx.doi.org/10.1089/cpb.2008.0228

Bosch, T.E., 2009, 'Using online social networking for teaching and learning: Facebook use at the University of Cape Town', Communicatio: South African Journal for Communication Theory and Research 35(2), 185-200. http://dx.doi org/10.1080/02500160903250648

Boyd, D.M. \& Ellison, N.B., 2008, 'Social network sites: Definition, history, and scholarship', Journal of Computer-Mediated Communication 13(1), 210-230. http://dx.doi.org/10.1111/j.1083-6101.2007.00393.x

Christofides, E., Muise, A. \& Desmarais, S., 2009, 'Information disclosure and control on Facebook: Are they two sides of the same coin or two different processes?' CyberPsychology \& Behavior 12(3), 341-345. http://dx.doi.org/10.1089/ cpb.2008.0226

Courtois, C., All, A. \& Vanwynsberghe, H., 2012, 'Social network profiles as information sources for adolescents' offline relations', Cyberpsychology, Behaviour and Socia Networking 15(6), 290-295. http://dx.doi.org/10.1089/cyber.2011.0557

Debatin, B., Lovejoy, J.P., Horn, A-K. \& Hughes, B.N., 2009, 'Facebook and online privacy: Attitudes, behaviors, and unintended consequences', Journal of Computer-Mediated Communication 15(1), 83-108. http://dx.doi.org/10.1111/ j.1083-6101.2009.01494.x

Dinev, T. \& Hart, P., 2004, 'Internet privacy concerns and their antecedents measurement validity and a regression model', Behaviour \& Information Technology 23(6), 413-422. http://dx.doi.org/10.1080/01449290410001715723

Ellison, N.B., Steinfield, C. \& Lampe, C., 2007, 'The benefits of Facebook "friends": Social capital and college students' use of online social network sites', Journal of Computer-Mediated Communication 12(4), 1143-1168. http://dx.doi. org/10.1111/j.1083-6101.2007.00367.x

Ellison, N.B., Steinfield, C. \& Lampe, C., 2011, 'Connection strategies: Social capital implications of Facebook-enabled communication practices', New Media \& Society 13(6), 873-892. http://dx.doi.org/10.1177/1461444810385389

Facebook, 2013, Facebook Newsroom, viewed 07 May 2013, from http://newsroom. fb.com/Key-Facts

Fogel, J. \& Nehmad, E., 2009, 'Internet social network communities: Risk taking, trust, and privacy concerns', Computers in Human Behavior 25(1), 153-160. http:// dx.doi.org/10.1016/j.chb.2008.08.006

Giannakos, M.N., Chorianopoulos, K., Giotopoulos, K. \& Vlamos, P., 2012, 'Using Facebook out of habit', Behaviour \& Information Technology 32(6), 594-602. http://dx.doi.org/10.1080/0144929X.2012.659218

Golder, S.A., Wilkinson, D.M. \& Huberman, B.A., 2007, 'Rhythms of social interaction: Messaging within a massive online network', Communities and Technologies 41-66.

Haferkamp, N., Eimler, S.C., Papadakis, A.M. \& Kruck, J.V., 2012, 'Men are from Mars, women are from Venus? Examining gender differences in self-presentation on social networking sites', Cyberpsychology, Behaviour and Social Networking 15(2), 91-98. http://dx.doi.org/10.1089/cyber.2011.0151

Hair, J.F., Tatham, R.L., Anderson, R.E. \& Black, W., 1998, Multivariate data analysis, 5th ed., Upper Saddle River, Prentice-Hall, NJ.

Hargittai, E., 2008, 'Whose space? Differences among users and non-users of social network sites', Journal of Computer-Mediated Communications 13(1), 276-297. http://dx.doi.org/10.1111/j.1083-6101.2007.00396.x 
Hew, K.F., 2011, 'Students' and teachers' use of Facebook', Computers in Human Behaviour 27(2), 662-676. http://dx.doi.org/10.1016/j.chb.2010.11.020

Hoy, M.G. \& Milne, G., 2010, 'Gender differences in privacy-related measures for young adult Facebook users', Journal of Interactive Advertising 10(2), 28-45. http://dx.doi.org/10.1080/15252019.2010.10722168

Internet World Stats, 2014, Internet usage statistics, viewed 13 February 2014, from $\mathrm{http}: / /$ www.internetworldstats.com/stats.htm

Junco, R., Merson, D. \& Salter, D.W., 2010, 'The effect of gender, ethnicity, and income on college students' use of communication technologies', Cyberpsychology, Behaviour and Social Networking 13(6), 619-627. http://dx.doi.org/10.1089/ cyber.2009.0357

Kalpidou, M., Costin, D. \& Morris, J., 2011, 'The relationship between Facebook and the well-being of undergraduate college students', Cyberpsychology, Behaviour and well-being of undergraduate college students', Cyberpsychology, Behaviour a
Social Networking 14(4), 183-189. http://dx.doi.org/10.1089/cyber.2010.0061

Kim, Y., Sohn, D. \& Choi, S.M., 2011, 'Cultural differences in motivations for using social network sites: A comparative study of American and Korean college students', Computers in Human Behavior 27(1), 365-372. http://dx.doi.org/10.1016/j. chb.2010.08.015

Kolek, E.A. \& Saunders, D., 2008, 'Online disclosure: An empirical examination of undergraduate Facebook profiles', Journal of Student Affairs Research and Practice 45(1), 1-25. http://dx.doi.org/10.2202/1949-6605.1905

Lewis, K., Kaufman, J. \& Christakis, N., 2008, 'The taste for privacy: an analysis of college student privacy settings in an online social network', Journal of ComputerMediated Communication 14(1), 79-100. http://dx.doi.org/10.1111/j.10836101.2008.01432.x

Miller, R., Parsons, K. \& Lifer, D., 2010, 'Students and social networking sites: The posting paradox', Behaviour \& Information Technology 29(4), 377-382. http:// dx.doi.org/10.1080/01449290903042491

Morris, M. \& Ogan, C., 1996, 'The internet as mass medium', Journal of ComputerMediated Communication 46(1), 39-50.

Muise, A., Christofides, E. \& Desmarais, S., 2009, 'More information than you ever wanted: Does Facebook bring out the green-eyed monster of jealousy?',
CyberPsychology and Behavior 12(4), 441-444. http://dx.doi.org/10.1089/ CyberPsychology
cpb. 2008.0263

Muscanell, N.L. \& Guadagno, R.E. 2012, 'Make new friends or keep the old: Gender and personality differences in social networking use', Computers in Human Behavior 28(1), 107-112. http://dx.doi.org/10.1016/j.chb.2011.08.016

Nosko, A., Wood, E. \& Molema, S., 2010, 'All about me: Disclosure in online social networking profiles: The case of FACEBOOK', Computers in Human Behavior 26(3), 406-418. http://dx.doi.org/10.1016/j.chb.2009.11.012

Paine, C., Reips, U-D., Stieger, S., Joinson, A. \& Buchanan, T., 2007, 'Internet users' perceptions of "privacy concerns" and "privacy actions", International Journal of Human-Computer Studies 65(6), 526-536. http://dx.doi.org/10.1016/j ijhcs.2006.12.001

Pallant, J., 2005, SPSS survival manual - a step by step guide to data analysis using the SPSS program, Allen \& Unwin, Sydney.
Pempek, T.A., Yermolayeva, Y.A. \& Calvert, S.L., 2009, 'College students' social networking experiences on Facebook', Journal of Applied Developmental Psychology 30(3), 227-238. http://dx.doi.org/10.1016/j.appdev.2008.12.010

Raacke, J. \& Bonds-Raacke, J., 2008, 'MySpace and Facebook: Applying the uses and gratifications theory to exploring friend-networking sites', CyberPsychology \& Behavior 11(2), 169-174. http://dx.doi.org/10.1089/cpb.2007.0056

Rafaeli, S., 1986, 'The electronic bulletin board: A computer-driven mass medium', Social Science Computer Review 2(3), 123-136. http://dx.doi. org/10.1177/089443938600200302

Roberts, K.K., 2010, 'Privacy and perceptions: How Facebook advertising affects its users', The Elon Journal of Undergraduate Research in Communications 1(1), 24-34.

Roblyer, M.D., McDaniel, M., Webb, M., Herman, J. \& Witty, J.V., 2010, 'Findings on Facebook in higher education: A comparison of college faculty and student uses and perceptions of social networking sites', The Internet and Higher Education 13(3), 134-140. http://dx.doi.org/10.1016/j.iheduc.2010.03.002

Ross, C., Orr, E.S., Sisic, M., Arseneault, J.M., Simmering, M.G. \& Orr, R.R., 2009 'Personality and motivations associated with Facebook use', Computers in Human Behavior 25(2), 578-586. http://dx.doi.org/10.1016/j.chb.2008.12.024

Schlenkrich, L. \& Sewry, D.A., 2012, 'Factors for successful use of social networking sites in higher education', South African Computer Journal 49, 12-24.

Sheehan, K.B., 1999, 'An investigation of gender difference in on-line privacy concerns and resultant behaviors', Journal of Interactive Marketing 13(4), 24-38. http:// dx.doi.org/10.1002/(SICI)1520-6653(199923)13:4<24::AID-DIR3>3.0.CO;2-O

Socialbakers, 2012, South Africa Facebook statistics, viewed 06 June 2012, from http://www.socialbakers.com/facebook-statistics/south-africa

Stafford, T.F., Stafford, M.R. \& Schkade, L.L., 2004, 'Determining uses and gratifications for the internet', Decision Sciences 35(2), 259-288. http://dx.doi.org/10.1111/ j.00117315.2004.02524.x

Stern, L.A. \& Taylor, K., 2007, 'Social networking on Facebook', Journal of the Communication, Speech \& Theatre Association of North Dakota 20, 9-20.

Valenzuela, S., Park, N. \& Kee, K.F., 2009, 'Is there social capital in a social network site?: Facebook use and college students' life satisfaction, trust, and participation' Journal of Computer-Mediated Communication 14(4), 875-901. http://dx.doi. org/10.1111/j.1083-6101.2009.01474.x

Vrocharidou, A. \& Efthymiou, I., 2012, 'Computer mediated communication for social and academic purposes: profiles of use and university students' gratifications', Computers \& Education 58(1), 609-616. http://dx.doi.org/10.1016/j.compedu. 2011.09.015

Weiser, E.B., 2000, 'Gender differences in Internet use patterns and Internet application preferences: A two-sample comparison', CyberPsychology \& Behavio 3(2), 167-178. http://dx.doi.org/10.1089/109493100316012

Yao, M.Z. \& Zhang, J., 2008, 'Predicting user concerns about online privacy in Hong Kong', CyberPsychology \& Behavior 11(6), 779-781. http://dx.doi.org/10.1089/ cpb.2007.0252 